\title{
Who are "the Expanded Doctors"? The Ethnography of Professional Self-Identifications in Polish Primary Care
}

\author{
Hubert Wierciński
}

DOI: 10.21104/CL.2020.1.02

\begin{abstract}
This article is an ethnographic exploration of the responses of doctors to the 1997 healthcare reform in Poland. Based on research carried out among practitioners working in Podstawowa Opieka Zdrowotna (POZ, "Basic Healthcare"), which was established in 1997 and opened up to the market, I demonstrate the newly emerged self-identification of doctors, which can be expressed by the term, "the expanded doctor". Following Elizabeth Dunn's and Asta Vonderau's ethnographies of post-socialist reconstructions, I examine how POZ practitioners became "expanded doctors", and what particular elements constitute this novel and liberal self-definition. Based on Eliane Riska and Aurelija Novelskaite's description of practitioners' experiences of transforming from a planned economy to a world composed of "four logics", I analyse the entrepreneurial face of the doctors' self-identification, their attachment to private ownership, and the cult of liberal capitalism.
\end{abstract}

\section{Key words}

healthcare reform, medical anthropology, primary care, Poland, postsocialism

\section{Contact}

Hubert Wierciński, Department of Ethnology and Cultural Anthropology, University of Warsaw, Żurawia 4, 00-503, Warsaw, Poland; e-mail: hubertwier@gmail.com.

\section{Jak citovat / How to cite}

Wierciński, Hubert. (2020). Who are "the Expanded Doctors"? The Ethnography of Professional Self-Identifications in Polish Primary Care. Český lid 107, 23-49. doi:http://dx.doi.org/10.21104/CL.2020.1.02 


\section{Introduction}

Since 1989 post-socialist healthcare systems have been undergoing major political and economic reconstructions. These changes have established concepts new to Central and Eastern Europe. Many of these were inspired by neoliberal discourses, bringing complex economics and new self-identifications to daily medical practice (Stone 1997; Koch 2013; Schecter 2011; Fotaki 2009).

As I consider such changes to be revolutionary, I will pay attention to precisely what new self-identifications have emerged in Polish posttransition healthcare. In this article I will focus on primary care - Podstawowa Opieka Zdrowotna (POZ, Basic Healthcare) - which, since 1997, has opened up to the market and entrepreneurship, albeit a version deeply embedded in local communities and their non-market issues.

Fundamental to my study is Elianne Riska and Aurelija Novelskaite's (2011) study of practitioners' experiences of the transformation from a planned economy to a world composed of "four logics", i.e., the state, their profession, informal economies and, ultimately, the market. This reorganisation also took place in Poland, prompting me to analyse doctors' experiences of the move from a centralised healthcare system to a liberal environment, i.e., a market logic - a space of intense reconfigurations and spectacular clashes between various contradictory discourses, actors, orders of knowledge and practices (McKenna 2012). Leaving the other "logics" aside, I explore how this change was perceived in primary care, and how physicians learned to work in previously unknown market settings.

Inspired by ethnographies revealing reconstructions in work and selfidentifications delivered by Elizabeth Dunn (2008a, 2008b) and Asta Vonderau (2008), I examine how the Polish primary care doctors established their new identity; an identity I term "the expanded doctor". This phenomenon finds, to some extent, analogies in Vonderau's concept of the "capitalist self" - the new post-transitional identity, "privatised and individualised", and "adjusted to the pace of capitalism" (Vonderau 2008: 114-115). I seek the foundations of this self-identification in the ideologies of the "transition culture" (Kennedy 2002; Kubik 2013), where entrepreneurship and neoliberal doctrines were considered an escape route from socialism (Verdery 1996; Dunn 2008a). Later, I examine the key elements grounding the self-identification of "expanded doctors", i.e., their endeavours and pioneering narratives of acting to transform healthcare, self-organise, and act upon their new independence from the state. Finally, I turn my attention to the sociocultural genesis of the doctors' new awareness of knowledge of the healthcare system, their strong attachment 
to private property, and their explicit interest in entrepreneurship, all signifying their "expanded doctor" self-identification.

\section{Theory}

Transitology narratives, healthcare and expanded self-identification

Each of the post-socialist countries has chosen its own way of reconciling its socialist past with its liberal present (Bazylevych - Hrešanová 2011). Some countries, such as Georgia, have surrendered their healthcare into private hands (Schecter 2011; Koch 2013). Others, like the Czech Republic, Romania, Hungary, Lithuania and Poland have attempted an interplay between the new social insurance systems and non-public healthcare entrepreneurship. As Elianne Riska and Aurelija Novelskaite (2011) point out, in such settings doctors live in four logics. They are involved in "informal economies", based on non-medical relations with patients and other social actors, whilst simultaneously determining their position in relation to state policies. Additionally, doctors adhere to professional and biomedical values that are globally affected by standardising trends (Timmermans - Berg 1997). The fourth logic of "the market" - the main point of interest here - appears to be one that rests on the other "logics". It obliges the practice and self-identification of doctors to confront a world of big economics, the state's position, and every-day market choices.

None of the above-mentioned shifts would have come about, had it not been for the transition. In Central and Eastern Europe, powerful transitology narratives have been playing a hegemonic role in thinking and acting in the post-1989 sociocultural reality (Kubik 2013). "Socialism is something to be escaped, repressed, destroyed", writes Michael D. Kennedy (2002: 13), perhaps inspired by work by Leszek Balcerowicz (1995). For these authors, the transition was a bridge to the "West", where neoliberal economics and freedoms are indisputable values. POZ practitioners often refer to this rhetoric. This narrative plays a crucial role in establishing the roots of doctors' self-identification, manifesting itself especially when they express their ideas about healthcare reform and relations with the state. Examples of this language can also be found in the doctors' critiques of the pre-reform and, according to my interlocutors, still "socialist" healthcare system that existed between 1989 and 1997. Socialism, understood here as a form of work and authority organisation in statedependent institutions, appears as a symbol of an utterly imbalanced, top-heavy system, in which goals have been crushed under the enormous weight of its own bureaucracy. Salvation, according to the doctors, lay in the "West" - a culture of private ownership and capitalism, allowing 
doctors to expand their duties, reinforce their economic positions, and establish new self-identifications.

Such an atmosphere laid the foundations for the phenomena described by Asta Vonderau (2008) in her study of the Lithuanian elite's self-representation after the collapse of the Soviet Union. Vonderau focuses on discourses on a good life, individual success, and social progress, predominately associated with westernisation, goods and status. While searching for new self-representation strategies, she simultaneously demonstrates how the transition is reflected in respondents' autobiographical portraits and their sense of "self" - an emancipating and imagined construct opening up paths to distinctive social environments.

New self-identifications - which I consider as contextual knowledge of "the self" installed in temporal social structures and relations - push social actors to reflectively reconstruct their biographies and address questions relating to their current positions. Hence, the transformation is not only an economic shift. Additionally, it is a map of new social stratifications, and a toolbox containing fresh concepts of individuality. Vonderau's "capitalist self" is one such idea, where individuality, mobility and self-responsibility are the crucial coordinates for "new individuals", who are

flexible, mobile, self-controlled, linear and consistent individuals, both in terms of actions and thoughts. The capitalist self is not only structured differently in terms of temporality but is deprived of its social environment - privatised and individualised (Vonderau 2008: 114).

Thus, the doctors' expanded self-identification that I am concerned with comprises a sense of endeavour. To become an "expanded doctor" means to dare to be one, to dare to strain against rusting chains of dependency, and to follow demanding yet emancipating transitology narratives. This might raise questions about the author playing the role of the doctors' neoliberal spokesman. I am not at all discouraged by this prospect, as I have seen the daily reality; observing the doctors helping their patients every day, and working long hours at home. I also see primary care doctors as being part of a diversified, local biomedical cultural system, which, as Robert A. Hahn and Arthur Kleinman (1983) have said, is composed of symbolic meanings, practices, labour divisions, and rules of power. In this system, POZ practitioners are subordinated to administrative institutions and market discourses. They are tired, as they work on contracts - the prize and the curse of the market - that fail to ensure basic workers' rights 
such as holidays and sick leave. Doctors also occupy quite a low symbolic position within the hierarchical biomedical community. Perhaps this fragile ground on which POZ has been founded should be read as the primal cause of the doctors "expansion" - a step forward, with the hope that the new system of healthcare will last long enough for its main beneficiaries to firmly establish themselves in this supposedly temporary world.

The reform

As with other Eastern Bloc states before (and for a while after) the transformation, the vast majority of Poland's medical units were centralised and state-dependent. Although free-of-charge access to healthcare was guaranteed to all citizens, this bureaucratic system was eroded by corruption, resulting in massive social inequalities. Shortly after the transformation, in Poland and other former Eastern Bloc countries, the state coffers were insufficient to cover the system's high costs, leading to underfunding, low wages and general frustration, both among healthcare personnel and patients (Czachowski 2002; 2005).

In 1997, the government reshaped Poland's healthcare system. The goals of the reform centred upon social insurance reconstruction and the introduction of new non-public agents headed by medical professionals contracted to the newly-established paying institutions (Kowalska-Bobko 2017). Since 1997, the core of the healthcare budget has been made up of the newly-introduced social insurance contributions. Between 1997 and 2003, healthcare insurance - a component of social insurance - was managed by 16 regional Kasy Chorych (Health-insurance Funds), which were the paying institutions responsible for contracting medical services. In 2004, after a spate of criticism focused on unequal budgets and bureaucracy, the Kasy Chorych were replaced by the Narodowy Fundusz Zdrowia (NFZ, "National Healthcare Fund"), which is now the sole public institution financing medical services. Each year the NFZ signs contracts with healthcare providers and transfers to primary care providers a fixed sum capitation rate (stawka kapitacyjna) for each patient referred for treatment. The rate may differ year by year, and may be affected by the patient's age and distinct medical condition. The final value of the capitation rate must thus be calculated after considering all additional indices.

After 1997, practitioners were encouraged to establish private partnerships (non-public healthcare providers) based on contracts signed with the paying institution (Włodarczyk 2000; Czachowski 2002). Simultaneously, the previously state-run primary care surgeries were gradually transformed into independent partnerships. Following the reform, many 
medical practitioners are now fully responsible for more than medical issues - they have become managers and employers competing with other clinics (Kowalska-Bobko 2017; Holecki et al. 2013). Currently, this competition is becoming more heated, as the value of a contract varies significantly between surgeries. The final value of a contract results from the number of patients assigned to a surgery, multiplied by the value of the capitation rate linked to each "type" of patient. Surgeries must cover all their costs and taxes, including outsourced medical and laboratory examinations. After settling all expenditures, the remaining money is the doctors' income. In some clinics, self-employed doctors issue a monthly invoice to the clinic for their services. In others, the final income is divided between the doctors according to internal regulations outlined in the particular partnership's agreement.

\section{Methodology}

\section{Research toolbox}

The ethnographic research for this text was conducted between 2014 and 2018, in seventeen clinics in the Podlasie and Mazowsze regions. Three of the clinics were in Warsaw, one in a nearby rural area, seven in Białystok, and six in small town / rural areas within ninety kilometres of Białystok. The results under consideration here are supported by three qualitative data sources. Firstly, I collected forty five semi-structured and unstructured interviews with practitioners working in the aforementioned clinics. Most of the interviews were conducted in the clinics, although, some took place in neutral locations. I see no substantive difference in their quality and content. The interviews, instead of aiming to deliver "factual" knowledge, were intended to reveal doctors' interpretations of the lived-experiences associated with their work. Thus, in line with classical narrative studies in medical anthropology (Frank 1995; Mattingly Garro 2000; Kleinman 1988), I stress the role of metaphorical and, at first glance, unclear interviewer statements, anecdotes and histories. I consider them as meaningful oral reflections of body-mind experiences embedded in doctors' biographies altered by shifting sociocultural factors, such as the transition or healthcare reforms. This perspective helped me overcome clichéd models of professional and biomedical cultures considered as static and standardized areas of Foucauldian institutional power (Välikangas - Seeck 2011; Timmermans - Berg 1997). The collected narratives convinced me to see the doctor's world as being composed of insecurity, hopes, expectations, victories and failures, together making it a very human world, and thus - cultural. 
Secondly, a part of my field notes was manufactured after observations. Unfortunately, this element was limited to only two clinics - one in Białystok, one in Warsaw. Consequently, many of the meaningful daily events and interactions in the clinics were hidden from my ethnographic gaze. I regret this, but I also understand that POZ surgeries are busy places, making it hard for an ethnographer to fit into such a hectic field setting. Additionally, I had to follow rigorous Polish legislation constraining non-medical individuals from acquiring data in the area of healthcare.

In the accessible clinics, thanks to the doctors' kindness, I spent long hours among patients waiting either for admission or with medical professionals, who - where possible - helped me to gain insights into their clinic's daily rhythms and work. Nevertheless, I consider these observations as non-participatory since I could not participate in consultations and procedures as I have no medical background. The only exception here was my presence during several non-serious follow-up visits, usually limited to renewing prescriptions or checking medical test results. Nevertheless, with the patient's agreement, I could observe "live" encounters between doctors and their protégés; something which I consider to be a form of "participation", albeit one limited to short, although ethnographically meaningful, events.

More fruitful was participation in gatherings of the Porozumienie Zielonogórskie ("Zielona Góra Agreement"), an association of healthcare employers representing the collective interests of POZ doctors. I was invited there by two independent informants who helped me to understand how the organisation operates and influences the doctors' professional identification. During regular meetings, I was exposed to performances meticulously prepared by doctor-activists, politicians and social agents, along with the spontaneous reactions of audiences composed of doctors. Usually, these reactions quickly turned into factual and, often, emotional dialogue leading to common statements and reactions to current political, professional, social and economic conditions. Thus, I was able to see the very moments, where many of the elements composing the doctors' identification - namely, knowledge, opinions and shared experiences - were born and later disseminated among the medical community.

Additionally, these meetings were an opportunity for establishing and maintaining personal interactions, reaching far beyond medical issues. These were the moments, where people met, often laughed or shouted, ate and drank together, and talked about personal and professional plans. In other words, the gatherings were a place of vivid social interaction among a specific group of professionals, whose worldviews, hopes and expectations were surprisingly similar. Thus, Porozumienie is not merely an 
association of healthcare employers - it is an elite professional club open, however, to non-owner doctors, activists and other social actors concerned about health policy. Thus, as some might consider the "capitalist self" people as being deprived of a social environment, my observations suggest the opposite. They are rather "tribalized" with people whom they share similar biographies, values and interests. As I have learned, despite the existing professional associations, such a situation was far more difficult before the emergence of Porozumienie, as the doctors did not have space for well-crafted interaction in which to share their worldviews and expectations.

Finally, in the article I use the knowledge gained after studying legal acts and key documents laying the foundations for POZ. These include the acts released by Ministerstwo Zdrowia (Ministry of Health) ${ }^{1,2}$ and Narodowy Fundusz Zdrowia (National Health Fund). ${ }^{3,}{ }^{4}$ To sketch the legal and economic context of POZ I refer to Cezary's Włodarczyk (2000) work exploring intersections between primary care and health policy in Poland. Additionally, I make use of quantitative, yet informative research delivered by health and social/political researchers, namely Sławomir Czachowski $(2002 ; 2005)$ and Iwona Kowalska-Bobko (2017). Finally, my interpretations are backed by discourse analyses of internet portals and professional magazines dedicated to $\mathrm{POZ}$, especially those published by Porozumienie Zielonogórskie. ${ }^{5}$

\section{The field}

In Podlasie, which is considered to be an economically underdeveloped part of Poland, the state plays a dominant role in providing healthcare services. There are some 300 contracted POZ clinics, where almost all interlocutors occupied full-time positions. The turnover of patients is low - patients have often been with their GP for a long time. Informants, especially those who worked in the small-town / rural areas, claimed that $\mathrm{POZ}$ clinics still play a major role in the local communities.

In the second region studied, Warsaw (ca 1.8 million inhabitants) and its surroundings, the role played by the state is more limited. The local healthcare market is visibly enriched by the private sector (based on vol-

\footnotetext{
1 https://www.gov.pl/web/zdrowie/ (accessed on 16.09.19)

2 https://www.gov.pl/web/zdrowie/podstawowa-opieka-zdrowotna (accessed on 16.09.19)

3 https://www.nfz.gov.pl/ (accessed on 16.09.19)

4 https://www.nfz.gov.pl/dla-pacjenta/informacje-o-swiadczeniach/podstawowa-opieka-zdrowotna/ (accessed on 16.09.19)

5 https://www.federacjapz.pl/ (accessed on 16.09.19)
} 
untary insurance contributions, company health care plans, and pay-pervisit appointments), which additionally often provides contracted primary care services. Consequently, a high turnover of patients and doctors is visible. Doctors choose more freely between different forms of practice. They can work for the state in private clinics, though following a precise range of duties, or they can sign a contract with one of the fully independent chain surgeries offering private insurance. None of the Warsaw informants worked solely in one clinic. Many of them combined independent institutions with those offering state-refunded services, spending a limited number of hours in each. Thus, the doctors rarely displayed an attachment to any one clinic and its patients, articulating flexibility as a defining characteristic of their professional self-identification.

The majority of the researched clinics were run by two to four doctors, with the exception of one clinic in Warsaw and two in Białystok. The small surgeries usually served a population of up to six thousand patients, with all doctors sharing the administrative duties. The bigger clinics had their own supervisory board coordinated by the doctor-owners, usually chaired by a doctor who occupied a full-time managerial position. Despite being supervisory board members, the doctor-owners still worked with patients, although their working hours were reduced, as the biggest surgeries employed part-time doctors, thus relieving the doctor-owners of the burden of full-time duties.

The majority of my interlocutors were females over fifty, however, gender diversity is less visible in larger groups, especially during doctors' regional meetings. These meetings also revealed that $\mathrm{POZ}$ practitioners constitute a homogenous group, although they do not share a uniform medical background. The majority of respondents first studied "internal medicine" or "paediatrics", followed later by "family medicine", the latter having been newly established in 1995 as a foundation for the upcoming healthcare reform. Before taking up positions in POZ, many doctors worked in public hospitals. Some of them held qualifications in postgraduate management studies or occupied consulting positions in pharmaceutical companies. The latter experiences were shared mainly by the doctors from Podlasie, who often could not find a permanent position in healthcare after completing their studies.

Such diverse professional experience resulted in doctors occupying different economic positions. Not all respondents were clinic owners. Some of them were salaried employees, contracted by clinic doctor-owners. Some of the respondents, especially the younger ones, neither worked in hospitals, nor had completed any postgraduate degree. This diversification, however, did not prevent them from sharing similar economic values 
and perspectives on healthcare. I consider this finding as one of the most striking conclusions of my research. The doctors often spoke about the healthcare system as a healthcare market, rather than as an institution of social welfare. Both young and senior doctors alike usually considered the state (and politicians) as an obstacle, rather than the party responsible for a well-functioning healthcare system. I heard many times about the inevitable necessity of patient co-payments and the introduction of additional private insurance, although none of the informants spoke directly of a healthcare system completely independent of the state. The critique was generally focused on limiting the state's role, rather than excluding it from organizing healthcare services altogether. This shows, that despite appreciating the liberal economy, the doctors still consider the state as jointly responsible for securing the healthcare system and shaping and promoting health policy.

\section{Interpretations}

\section{Pioneers and endeavourers}

It was common for the doctors who experienced the reform to portray themselves as active agents of transformation, almost sacrificing themselves to speed up socio-economic progress. The metaphorical "reform" - the passage from centralised healthcare to the freedom of non-public practices - is the leitmotif around which the doctors ordered their stories of the post1997 changes. The story of the reform - its foundation, and later its defence against the more conservative-leaning successor authorities - plays the role of the founding myth of primary care. It is collective, as described by the majority of the doctors (with the exception of the youngest informants), and anchors their current self-identification to momentous past events, such as the difficulties inherent in starting their own businesses, or their first clashes with local authorities reluctant to loosen their control over healthcare practices. In these stories the plot is often compressed, with the action moving on to 2003/2004, when the doctors started their massive strikes against the new state policy, and when the newly established Porozumienie Zielonogórskie (Zielona Góra Agreement) appeared on the political scene.

As Richard Jenkins (2008) states, the creation of a meaningful past, juxtaposed with institutionalisation and performance, is a key mechanism for transmuting purely mental identifications into practice. Stories of the past help order the contemporary social reality and enrich an individual's future plans. They are created by those who have experienced certain social changes - like the doctors, exposed to new policies, who now reflexively deconstruct their path to their current positions and speculate about 
future challenges. This path was exceedingly bumpy, leading through a labyrinth of semi-transparent decisions and informal actions. Many of their stories about setting up clinics were embellished with now amusing, but back then very serious, tales about coming to terms with the new act on healthcare, mastering the byzantine rules of contracting practices, establishing partnerships, and finding proper premises for their clinics. Informal gifts to local officials were then common - a bottle or two of Johnny Walker (a '90s symbol of luxury) turned out to be of invaluable help, especially during "negotiations" between the doctors and housing cooperatives that had at their disposal appropriate real estate.

This practice is reminiscent of Riska and Novelskaite's (2011) world of "logics" covering the concept of "the informal economy", based on personal collocations and under the table services and favours. Nevertheless, I view the process of becoming an "expanded-doctor" as a story of gaining skills in wangling services and pacifying often unexpected social actors skills that most of the doctors, unused to acting in such conditions, simply did not have. Most of their careers up until then, with the exceptions I will discuss later, were spent in hierarchical and centralised biomedical institutions, where the "informal economy" was predominately limited to undeclared interactions with patients, such as soliciting additional payments or other goods and favours. Doctors were implicitly subordinated to their superiors and overwhelmed by the harsh job conditions which are well-illustrated in the following story:

\begin{abstract}
My job in the hospital where I worked was a nightmare, because there were 82 patients in the ward, and the patients, of course, also occupied the corridor. During the night shift, which I usually shared with a friend, I was supposed to do the full round. So, please count - 82 multiplied by 5 minutes for each patient... So, we just flew through the ward like planes. [...] It was a nightmare. After one shift I told myself that I would like to live perhaps ten more years (Contract doctor, female, 50, Warsaw).
\end{abstract}

Thus, doctors leaving public institutions sought to break the patterns of dependency and remove themselves from the exhausting treadmill. However, at the beginning of their non-public activity, perhaps charmed by the government's guarantees and promises, they did not expect to be confronting previously unknown institutions (along with their patterns of informal interactions), and entering into new power relations. Neither did they expect to be starting their long struggle for emancipation and a stronger position in negotiations with new social actors. This struggle, as I have 
learned from the doctors, has not yet finished. The practitioners still have to confront the national payer (NFZ), social insurance agencies (ZUS, KRUS - Kasa Rolniczego Ubezpieczenia Spotecznego, Farmer's Social Insurance System), local authorities, leasing managers, laboratories and even garbage collection companies, all reluctant to lower the costs of their services.

Many doctors presented themselves as brave pioneers facing up to the economic risks of running a business and overcoming obstacles on the path to capitalist freedom. They told stories of becoming new, active doctors and politically-engaged citizens dealing with previously unexpected medical, economic and social issues. However, following and defending the aims of the reform turned out to be a real transitional experience, encompassing periods of prolonged, stressful strikes against the state's anti-reform policy - notably in $2003 / 4$. At that time, the interlocutors found themselves in an insecure moment. The doctors feared that the new authorities intended to halt the reform and cut the costs of providing primary care by loading additional duties onto doctors' clinics. In effect, they faced the threat of the constriction of their professional autonomy and the loss of their jobs, or a significant proportion of their incomes.

In 2005, this stressful situation recurred with public threats from the government. Ludwik Dorn, then Minister of the Interior and Administration, threatened protesting doctors, saying that for their defiance they would be forcibly drafted into the army, thereby bringing back memories of a practice often used by the communists to break the opposition. Such threats, along with the government's restrictions, only strengthened doctors' distrust of the state, seriously complicating relations for several years to come. But this also had a profound impact on their self-identification, now clearly driven by anti-state sentiment and a need for socio-political engagement.

Doctors told me that, at least in the initial phase, the reform, aimed to not only change the healthcare system, but also stimulate practitioners' agency and their social engagement. To do this, the doctors mastered a new language. Following Elizabeth C. Dunn (2008a; 2008b) and Asta Vonderau (2008), it is fair to say that they acquired an emancipating, neoliberal, "self-regulation" or "capitalist-self" discourse that emphasises individual power. Some of their actions, like the emergence of the Porozumienie Zielonogórskie, which was governed by a group of dedicated individuals (some of whom were my informants), successfully opposed the state and reshaped the health-policy scene. Porozumienie not only helped practitioners articulate their demands and protect their businesses, it also established a collective self-identification for POZ practitioners, one distinct from those in other branches of healthcare: 
Specialists in a particular subject matter also work here. Nevertheless, we are treated as universal labour, so, labour focused on nothing. In Poland other specialists think that a family doctor is a doctor ready to do everything that the specialist doesn't want to do, or doesn't have time for. We are the specialists in our field, we have our duties, we have our job to do, we are not the specialists' servants, just executing their demands and dispensing sick leave, because they are too lazy to do it (Clinic co-owner, female, 58, small town, Podlasie).

My observations show that this self-identification is constantly refreshed at regular meetings of Porozumienie Zielonogórskie. During gatherings, physicians and activists discuss the major current challenges in politics and healthcare, as well as legal, medical and practical issues in POZ. For many, Porozumienie is also the first and the most reliable source of information on current healthcare issues. Thus, through consociation and critique of government(s) and other healthcare branches (especially hospitals and their organization), practitioners demonstrated how the essences of the reform - freedom, emancipation, decentralisation and privatisation - had been discarded.

The doctors' vote against state policy was especially visible (to patients as well) during the massive strikes between 2003 and 2005, when many doctors closed their clinics, thus opposing the unpopular NFZ and state policy forcing doctors to extend services and bear the brunt of growing costs. The tempered reform, as I heard, smothered doctors, whilst simultaneously giving them a reason to engage in an emancipating and self-organising critique, evoking memories of Solidarity narratives, exhorting them to unify, and resurrecting belief in the power of resistance. This also strongly suggests that the transition in healthcare has always been a utopian project. None of the social actors involved - neither the doctors nor the state - were able to compromise regarding their expectations. To this day, there are significant tensions, since a sense of distrust clouds relations between POZ doctors and state officials. Remarkably, almost all key positions in the Ministry of Health and NFZ are occupied by doctors, who, after joining these structures, irretrievably lost their background authority. A critical speech about the ex-minister of health - Konstanty Radziwiłł (also a POZ practitioner) - delivered by one of the key members of Porozumienie Zielonogórskie illustrates this: 
You ask me if the minister is our friend. And I tell you, the minister previously happened to be our friend. Miodow $a^{6}$ changes people (quotation from field notes).

Radziwiłł was dismissed in January 2018, in an atmosphere of scandal and mistrust, after his grave mishandling of the resident doctors' protest, ${ }^{7}$ demanding rapid reforms of the healthcare system. POZ doctors and Porozumienie played their part - not without a certain satisfaction - in the minister's dismissal. They heavily criticised the Ministry after the incoming POZ reforms were announced. This shows how complex the post-transformation logics can be. The research indicates that usually the sense of distrust towards elites and the political class is shared by those for whom the transformation was a form of degradation. Here, however, the emancipated doctors also share a deep distrust toward politicians (even doctorpoliticians) and social institutions, accusing them of rabid conservatism and centralistic practices. On the other hand, the rather showy speeches of Radziwiłł - a POZ practitioner who, let's not forget, came lately to politics,- revealed his deep distrust of, and lack (or loss) of professional solidarity with young doctors and fellow POZ practitioners. Here are some examples:

Gross salaries are now about between 3170-3890 PLN [730-900 Euros]. These are not starvation salaries. We live in Poland here and now. These are low, but not starvation salaries (Radziwłł on young doctors' salaries). ${ }^{8}$

And another one is as follows:

Now the protest strikes, when the "hospital net" that has not been criticised by anybody is coming to be fully operational. I don't want to say that this is a political protest, but undoubtedly, it has become so (Radziwiłł on the 2017 practitioners' protests). ${ }^{9}$

6 Miodowa is the street in Warsaw where the Ministry of Health is located.

7 The position of resident is for doctors who wish to complete a specialisation in one of the branches of medical practice. Their salary, low even by Polish standards, comes from the Ministry of Health budget. A resident's training usually lasts around six years. The majority of residents take extra jobs and work extremely long hours, often in unfavourable conditions.

8 https://www.tvn24.pl/wiadomosci-z-kraju,3/konstanty-radziwill-wszystkie-protesty-ministra-zdrowia, $803655 . h t m l$ (accessed on 16.09.19)

9 http://wyborcza.pl/7,75398,22518036, minister-radziwill-podmiotem-w-sluzbie-zdrowia-sa-pacjenci.html (accessed on 16.09.19) 
Such accusations and divisions only strengthen the doctors' self-identification and convince them that if healthcare is to be seriously reconstructed, the reform should be first and foremost "normalizing".

Normalizing reform, westernisation and entrepreneurship

To begin with, let us return to the classics of post-socialist ethnography. Elizabeth C. Dunn writes:

New governing technologies, representing a neoliberal perspective on autonomy and activity, have promised the birth of a new person: active, mobile, decisive. The idea of "being flexible" and producing flexible workers meant to be the antidotes for socialism - a kind of freedom contrasted with communist limitations (Dunn 2008a: 193).

Indeed, in the collected stories, socialism comes across as a naïve system of structural dotage embedded in a time of ill-knowledge and doctors' inability to act. The reconstruction of the centralised healthcare system has, according to informants, uplifted doctors and opened their eyes to previously unknown issues. The doctors stressed the "normalising" role of this rebuilding, as it was interpreted as the first market-grounded attempt to resuscitate a system that was already living on borrowed time.

The doctors' critique was not limited to the pre-1989 era. The period 1989-1997 was also seen as unfair isolation from socio-economic changes. The practitioners had the impression that they were side-lined from the transition and forced to play a limited role - that of mere witnesses to the changes, as opposed to being their direct beneficiaries. Thus, the new concept for primary care was perceived as the long-awaited anti-socialist breeze of westernization blowing over the doctors, with all its blessings and benefits:

It's a hell of a difference! What existed before the reform was simply communist. Actually, to be honest, nobody was concerned how the system worked or how things were going (Clinic-owner, male, 50, village, Podlasie).

In the early ' 90 s many practitioners (some of them my informants) participated in foreign internships as part of the PHARE (Poland and Hungary Assistance for Restructuring of the Economy) programme, mainly in the Netherlands, Denmark and Great Britain. According to their accounts, there was an evident abyss between pre-reform Polish healthcare 
and the systems they observed abroad. This observation did not only refer to the doctors' earnings. Abroad, the practitioners were supposed to work in incomparably more flexible environments, once again invoking Riska and Novelskaite's (2011) "logics". However, it was the "market" - not the informal economy, professional hierarchy or state policy - which played a key role in providing healthcare services and increasing their quality. Those who participated in the PHARE exchange later became local leaders in the "westernisation" of Polish healthcare:

There was a group which visited different European countries to observe how things were done there, how education was organised, because back then in Poland we had to build everything from scratch. Later, the dozen or so who went set up the department here in Biatystok. Our slightly older colleagues became our teachers. They shared with us the knowledge they had gained abroad. Actually, it was the non-medical know-how, because we knew the medicine, but not the organisational stuff, since here a "doctor" is synonymous only with conditions and treatment, but there - it's different. (Clinic co-owner, female, 57, activist, Białystok)

Although they enriched doctors' knowledge, the PHARE internships, were also a part of the naturalization of the incoming transformation of Polish healthcare, which was politically supported by the World Bank and EU structures. Thus, similar to Asta Vonderau's (2008) reflections, I consider the naturalisation of the reform as a project designed by liberal proponents aiming to influence entire social groups and their individual members' self-identifications. I have found traces of this influence in stories related by participants in PHARE internships, which evoke ethnographic descriptions of "initiation" - a temporal exclusion, a journey "there" to master certain knowledge and experience a specific enlightenment, and finally, becoming a mature person ready to teach others. This transitional-initiatory motif was also characteristic of the doctors' stories of starting businesses and learning how to run them. The free market and capitalism appear uncritically in these stories as maturing factors, prompting social modernisation and individual progress. The doctors who established private partnerships, after stressful adaptations and harsh beginnings, gained a new "awareness" of how a modern healthcare system should work:

Awareness amongst doctors has changed. They run their businesses, so they take care of their companies, they take care of standards, 
and they are focused on what's new. You know, additional training, implementation of new standards and procedures, this also benefits patients (Clinic co-owner, female, 54, Białystok).

And here is another example:

\begin{abstract}
Before privatisation, and by this I mean before these private units with contracts with the NFZ or the Kasy were established, everything was put into a single state-cauldron. The doctor never thought about the costs they generated. The patients had everything, and, because of that, the state was falling into debt, because somebody had to pay. Nobody was aware, because there was no capitalist thinking as such, there was just the old, socialist thinking: I don't pay, so I'm not interested. And it is only the establishing of these private clinics with contracts that has made doctors think, and the patients have started to as well. This only happened in the late "90s, when "family medicine" was established. This specialisation stimulated the real reform, because family doctors were created, and in '97 the government changed the law, and people could start their own businesses. (Clinic co-owner, male, 56, Białystok.)
\end{abstract}

The data under consideration here suggest that many aspects of doctors' activities - other than medical duties - have also evolved. The doctors now have access to additional training which is not just limited to expanding their medical knowledge. Some of my respondents participated in coaching sessions focused on interactions between people, and many also completed postgraduate management studies. Thus, primary care is medicine that has its own entrepreneurial values and standards. As it is practised predominately in private clinics, doctors can implement innovative solutions in their practices, such as, better communication, efficient management or advanced software to organise schedules and registration.

Nevertheless, all these amenities cost money, and POZ is a branch of healthcare where costs are more visible than elsewhere as doctors have to balance their budgets. Thus, apart from "normalisation," the reform also brought a "price revelation" for doctors. Doctors discovered medicine costs, since prior to 1997, the centrally distributed money (always insufficient and non-transparent) was an abstract issue managed by distant people with power in administrative institutions. This discovery has had profound consequences for those entrepreneurs running their own companies: 
If I wanted to check patients' blood results every month, then we would have to close the surgery and say "thank you, we've gone bankrupt". The Ministry looks only at doctors' incomes, but it never thinks that, actually, the doctors only earn from those patients who never come. Not from those who come, because they need to be diagnosed. Now we have more and more elderly people, who really need extra examinations, which we conduct. And this generates huge costs (Clinic co-owner, male, 53, Białystok.).

As Deborah A. Stone (1997) states, introducing market economics to medical practice always entails new definitions of how medicine should be defined and practised. Stone argues that bringing the culture of market economics to the culture of medicine was a global cultural revolution, altering not only the values associated with medicine, but also strongly affecting doctors' self-identification, since they are "economic actors just like everyone else" (Stone 1997: 546). Thus, being a doctor-businessperson in a non-public surgery is exactly Stone's cultural revolution made real, a fundamentally new concept for practising medicine in Poland. In the reformed primary care system, the traditional role of the practitioner, which was up until 1997 predominately associated with a pro-social but centralised and inefficient welfare system, has been exposed to modern economics and market challenges. Entrepreneurship has opened up many new possibilities and offered doctors a certain measure of independence, but most importantly, it has strongly affected their self-identification. Now, the doctors see themselves as practitioners, businesspeople and managers focused on a vast range of duties and having many more responsibilities than just treating patients. To back up my interpretation, here are some statements that refer to doctors' expanded self-identification:

It is just as it is in every other business, but, as the owner and the employer, I have certain duties. I must keep an eye on my nurses, on their social insurance, I have to follow the labour law, and also, like every employer, I have to take care of sanitary-epidemiological issues. In the big surgeries, there is a director and his or her deputy who take care of everything. And here, I am both director and deputy. I am the owner, stockist, errand runner, literally everybody! (Clinic-owner, male, 50, village, Podlasie).

And another one:

We have the same challenges as any person who has their own business. Besides being a doctor, you have to be an entrepreneur, and this is 
hard. It makes me mad sometimes - I can't focus on being a doctor because I have to be an IT manager, I have to know something about air conditioning, do the shopping, and fix my computer. You really have to be entrepreneurial, open, creative and you must be eager to do this job, as there is no other way to do it (Clinic co-owner, female, 58, small town, Podlasie).

In this expanded environment, private ownership, as I was told many times, was the only "normal" and fair way of organising primary care. Running one's own business or working in a private clinic was the right way to be a "modern" doctor, which meant having more responsibility than the average former ZOZ (Zaktad Ubezpieczen Społecznych, Social Insurance Facility, state-run clinic) employee, who was stripped of all responsibility, poorly paid and deprived of valued agency and flexibility.

Founding a POZ clinic, or working in one, empowered doctors' symbolic capital. Many of them located themselves at the peak of the sociocultural revolution brought about by the transformation. This self-privatisation of their jobs and identities resembles the tale of the privatised and independent "capitalist self", grabbing the new economic reality by the horns. I learned from the doctors, however unfair and generalizing such declarations can be, that those who remained attached to state-controlled institutions were seen as "losers", lacking the social and resourceful capital that is much-valued in the post-socialist context (Buchowski 2006; 2012). In fact, my earlier research experiences in hospital wards show that doctors working there can certainly not be described as "losers". They often work in state and private institutions, choose more flexible job agreements and participate in training that requires knowledge and experience often inaccessible to POZ practitioners. Some of my informants - such as, Anna and Magda, who are Białystok paediatricians- combined their basic jobs in hospital with extra hours in POZ. When comparing these two areas, both women suggested that work in POZ was less demanding and tailor-made for those who do not cope well with pressure or prefer a calmer and more stable work rhythm. Additionally, it should be remembered, that I am dealing here with narratives delivered by a relatively young professional group, still looking for its proper recognition and place within the biomedical hierarchy. Thus, the criticism concerning secondary and hospital medicine I interpret not as a reporting on the factual situation, but rather as a result of the informant's professional insecurity, and the rather low opinion of primary care within the visibly hierarchical Polish biomedical culture. 
Nevertheless, the advent of non-public contracted surgeries has changed doctors, leaving them at first somewhat disoriented, albeit eager to acquire knowledge of their new professional milieu. However, it has not been easy. Notably, difficulties accumulated just after the reforms were introduced. Most of the doctors were unprepared for the new conditions - they had never run businesses, nor could they find any pointers in their educational background. Even those who were trained to be a pioneering generation had serious problems keeping up with the pace of changes. The words of one of my key informants clearly illustrate this point:

I and my friends knew theoretically what Kasa Chorych was and what it was all about, so we decided we were going to have a few months' break after doing our very demanding specialisation practice and internships. Later, perhaps in March or April, we would open a practice. We had been trained to set up our own business, in our own surgeries with our lists of patients. But in October a state consultant came to us, and the girls said to me: listen, why don't you read this new act to figure out what these Kasy are all about? Maybe we need to do something we don't know about? So I met the consultant and said: listen, this is the way things are - we have just passed our exams, what do we do now? And he said: What?! March or April?! Forget $i t$, they'll be awarding one-year contracts and the bidding starts in December! Okay, but it's October, so we should already have practices and patients now. How on Earth can we set it up right now? And he said - I don't know how, but you have to set it up! After that, we had a historic meeting in a pub, where we tried to figure out what we really wanted. And we came to the conclusion that we wanted a practice, but wondered how we could achieve it and where we would get the money from? It's funny - we realised we didn't have any money, but if our husbands didn't want lazy housewives, then they would have to cough up (Clinic co-owner, female, 57, activist, Białystok).

However, not all doctors have had to operate to such tight deadlines. Practitioners previously occupying managerial positions in state run surgeries - like one of my informants who is now running his own clinic in a rural part of Podlasie, and one chairing a partnership which owns a clinic in Białystok - have quickly mastered the new regulations and made themselves comfortable in non-public surgeries. Also, doctors with experience of working for pharmaceutical companies have recognised the 
new POZs as being attractive job opportunities. In the '90s some of my respondents had difficulties in finding positions as doctors. As a result, they turned their attention to pharmaceutical companies who were then intensively seeking qualified personnel with backgrounds in the medical sciences. This is how one of the clinic co-owners recalled her first steps:

Tou take your degree, then you do an internship, and then you start thinking about your future, as there is no job for you. That was my case - I worked in a pharmaceutical company and voluntarily completed a specialisation in pulmonology. That was a satisfying job - because of the money - but still I knew I would be a doctor one day. I treated that job as a temporary job. [...] When I was starting out, there were no other options. The companies only hired doctors, dentists and pharmacists. [...] There were substantive training courses there, some meetings with recognised researchers, and that gave me a lot of knowledge. These were really hard-science lectures, but the job in general was disappointing. I started in '94, at that time it was something, a job in a pharmaceutical company had a bit of a different prestige. But I truly believe that a doctor should be a doctor, not a pharma agent. In the West perhaps nurses do this, or people with an average education. Here, however, it was a kind of novelty, people were mesmerised, and because there were no jobs, it just happened that way.

\section{- Did you learn anything there?}

- Yes. Marketing and managerial skills, perhaps. Now it's important, as this is a very independent job. Management - that gave me a degree of independence (Clinic co-owner, female, 54, Białystok).

And there is a declaration from a doctor with a strikingly similar professional biography below:

As I worked for pharma, I had a lot of "difficult-customer" training sessions. That job gave me proficiency in computers, a driving license, psychological training, showed me how to make contact with other people, but also gave me a certain sense of entrepreneurship, as I was running my own business activities. I had to write a lot of reports and do the other stuff, what's it called, kind of organisational stuff. I work as a doctor about five hours a day, the rest is the work around that - social security, the NFZ, shopping, toilet paper, coffee, medi- 
cines, syringes, needles. [...] I am drawn to working for myself. After so many years of being a freelancer, I can't even imagine a position in a hospital or working for somebody. I worked in a pharmaceutical company when it was a pleasure. That gave me satisfaction, I wanted to run my own business, and now I want to be a rudder, a ship, a sailor and be responsible for my job (Clinic co-owner, female, 58, small town, Podlasie).

Both interviews were conducted in neighbouring towns in Podlasie, where in the ' 90 s many doctors had very poor chances of finding jobs commensurate with their qualifications. This sounds quite ironic today, when in contemporary Poland nearly every hospital and specialist surgery struggles with personnel shortages, enormous waiting lists and massive frustration, from both overworked doctors and disappointed patients. Nevertheless, a managerial background and a fully independent job with a strictly market-grounded company expressly helped my informants with running their own businesses, whilst also strongly shaping their needs and expectations. Neither of the doctors see themselves moving back to a hierarchical hospital structure or as employees of other people. Both of them were active members of Porozumienie Zielonogórskie and took part in the all the protests organised by the organisation.

I see a certain connection here. Podlasie, somewhat saturated with rather small surgeries, often founded by doctors coming back from a type of exile in pharmaceutical companies, is one of the parts of Poland most engaged in Porozumienie. A large number of Podlasie surgeries are members of the organisation and, during the aforementioned protests, the entire region was almost completely paralysed - on the appointed date, doctors simply did not open their businesses. Therefore, paradoxically, Porozumienie - a quasi-labour union, although founded by people holding capital and with a certain agency - became an environment steeped in neoliberal discourse, disseminating a certain type of strong self-identification. "Why" is not a mystery anymore, since so many of its members are precisely that kind of doctor, with market-based work experience and a strong attachment to independence, flexibility, private ownership and other liberal values, all of which are characteristics of the self-identification of "expanded doctors". 


\section{Conclusions}

I see the investigations exploring the sociocultural contexts in which doctors are educated, work and live as being particularly important, as I believe biomedical culture is ethnographically rich, although too often narrowed down to somewhat clichéd concepts of medicalisation, biopower and wealth. However, questions might now be raised concerning the influence of the doctors' purely economic position on their self-identification. Such questions are valid, as Polish doctors are often accused by the public of parsimony and a singular focus on luxury. My research has revealed that some doctors do, indeed, belong to the financial elites in their cities, towns, and villages - especially the clinic owners. This economic position has some impact on the doctors, but money is not the sole identification factor. Most of the practitioners spoke about liberal values, engagement, motivation and freedom (both economic and from state control), and creating a specific capitalist climate, in which money is more a fitting reward than a goal in itself. Additionally, many POZ practitioners are far from being unusually well-off. It was mainly the younger generation - contract doctors and residents - who had poor chances of establishing their own business, as the network of existing clinics is already very dense. Another issue is demography and simple economic calculations. Polish society is getting older and diminishing in size. According to Główny Urząd Statystyczny (GUS, Statistics Poland), the next three decades will see the population of Poland shrink by approximately 3.1 million people to 35 million. ${ }^{10}$ These facts were noted by my interlocutors, especially those from rural areas where, after Poland's 2004 EU accession, depopulation was observed in the wake of intense economic migration. They complained that they had fewer and older patients in their surgeries - falling patient numbers from five thousand to three thousand over the last decade were reported. As a result, the value of contracts is lower and general costs higher, because of the reduction in patient numbers and the higher costs of treating the elderly. In some cases, there was little chance of the businesses remaining profitable, and my research allows me to speculate that many of these unviable clinics located in rural settings have already been put up for sale, or will be in the near future.

As Peggy Watson (2013) critically remarks, the reform has produced immense diversification and inequality among patients. This, in turn, has also affected POZ doctors, who, despite their new self-identification and

10 http://stat.gov.pl/obszary-tematyczne/ludnosc/prognoza-ludnosci/prognoza-ludnosci-na-lata-2014-2050-opracowana-2014-r-,1,5.html (accessed on 05.04.2019). 
social position, have become dependent on many indeterminate agents. According to doctors, the strong position of the NFZ and persistent, lingering bureaucracy represent the reform's main failure. The resurgence of monopolistic practices halted the transition and caught doctors up in a quasi-liberal healthcare system. This regression encapsulates the experience of transition stuck in a moment, stranding doctors in the antechamber of a free healthcare market. Consequently, doctors have had to act in an ephemeral world in which, today, nothing is predictable, and the future prosperity of their clinics has to be hard-won in interminable struggles with the NFZ and the Ministry of Health.

Current departmental work on forthcoming POZ reforms assumes a major reconstruction of the financialization of the work of doctors. However, despite the Ministry's declarations, no precise details of this reconstruction are yet known, thus making practitioners once again anxious about the profitability of their businesses and the continuity of their entrepreneurial expanded self-identification. The extensive body of critical literature on policy, healthcare reforms, privatisation, financialization and labour shifts, both in developing and developed countries (Abadía-Barrero 2015; Dao - Nichter 2015; Rylko-Bauer - Farmer 2002) documents well similar phenomena in other parts of the globe, and reveals major instabilities and severe cracks in constantly evolving healthcare systems. These cracks often run parallel to the formation of new power relations in these systems, as well as the dissemination of neoliberal policies and growing tensions between global economic trends, patient demands and new practitioner self-identifications.

The impact of neoliberal discourses and the dramatic entrance of economics into health matters are reflected in the POZ doctors' self-identifications. My research, like other ethnographies of post-socialism, has revealed that doctors' self-identifications emerge from a complex interplay between local socio-cultural values and the socio-political factors, ideologies and power relations disseminated by neoliberal discourses and practices. In a world with - as the doctors would say - an unleashed economy, practitioners quickly recognised the chances for making their liberal dreams come true. Now they are the "expanded doctors", who, like Asta Vonderau's (2008) and Elizabeth Dunn's (2008a; 2008b) "new people of transformation", are armed with their "capitalist self", take care of their patients, run businesses, control standards in their clinics, follow the latest developments in medicine and healthcare management and interact with a number of other social actors and business entities.

Doctors have become busy and responsible entrepreneurs, for whom passiveness and a lack of intense activity are predominately associated 
with the still not-well-defined "socialism" of the past. The terms "socialism," or less often "communism", were usually used by the doctors to contest or discredit certain political environments or economic practices. Strikingly, doctors employed these negative epithets to illuminate phenomena rarely convergent with the period of Polska Rzeczpospolita Ludowa - the Polish People's Republic. Commonly, the doctors accused the governments in power in the periods 1989-1997 and 2004-2007, and also contemporary authorities, of a socialist doltishness that was halting socioeconomic progress, which was almost always equated with liberal capitalism. To make their voice stronger, they organised a series of strikes and established an umbrella organization - Porozumienie Zielonogórskie. Yet, it may seem ironic that thanks to a quasi-labour union they quickly organised themselves around liberal values and reformist demands. One thing is clear, despite this seeming incongruence, the role played by Porozumienie accelerated the emergence of POZ doctors' self-identifications and helped them to achieve their current social position. Yet, this position is not a finished project, nor is it fully secured against unpredictable state policy, leaving involved parties - both doctors and the state - in a tense situation of mutual distrust.

October 2019

\section{References}

Abadía-Barrero, César. 2015. Neoliberal Justice and the Transformation of the Moral: The Privatization of the Right to Health Care in Colombia. Medical Anthropology Quarterly 30, 1: 62-79.

Balcerowicz, Leszek. 1995. Socialism, capitalism, transformation. Budapest: CEU Press.

Bazylevych, Maryna - Hrešanová, Ema. 2011. Introduction: Health and Care Work in Post-Socialist Eastern Europe and the Former Soviet Union. Anthropology of East Europe Review 29, 1: 1-7.

Buchowski, Michał. 2006. The Specter of Orientalism in Europe: From Exotic Other to Stigmatized Brother. Anthropological Quarterly 79, 3: 463-482.

Buchowski, Michał. 2012: Anthropology in Postsocialist Europe. In: Kockel, U. - Craith, M. N. - Frykman, J. (eds.): A companion to the anthropology of Europe. First edition. Singapore: Blackwell Publishing: 68-87.

Czachowski, Sławomir. 2002. Środowiskowe uwarunkowania praktyki lekarza rodzinnego (wybrane zagadnienia). Toruń: Wydawnictwo Naukowe Uniwersytetu Mikołaja Kopernika. 
Czachowski, Sławomir. 2005. Rola lekarza rodzinnego w praktyce medycznej. Toruń: Wydawnictwo Naukowe Uniwersytetu Mikołaja Kopernika.

Dao, Amy - Nichter, Mark. 2015. The Social Life of Health Insurance in Low- to Middle-Income Countries: An Anthropological Research Agenda. Medical Anthropology Quarterly 30, 1: 122-143.

Dunn, Elizabeth C. 2008a: Prywatyzujac Polskę. O bobofrutach, wielkim biznesie i restrukturyzacji pracy. Warsaw: Wydawnictwo Krytyki Politycznej.

Dunn, Elizabeth C. 2008b: Subjectivity after Socialism: An Invitation to Theory Building in Anthropology. In: Schröder, Ingo W. - Vonderau, Asta (eds.): Changing economies and changing identities in postsocialist Eastern Europe. Berlin: LIT Verlag: 225-235.

Fotaki, Marianna. 2009. Maintaining the Illusion of Free Health Care in Post-Socialism. A Lacanian Analysis of Transition From Planned to Market Economy. Fournal of Organizational Change Management 22, 2: 141-158.

Frank, Arthur. 1995. The wounded storyteller. Body, illness, and ethics. Chicago, London: University of Chicago Press.

Hahn, Robert - Kleinman, Arthur. 1983. Biomedical Practice and Anthropological Theory: Frameworks and Directions. Annual Review of Anthropology 12: 305-333.

Holecki, Tomasz et al. 2013. Kształtowanie wizerunku placówki podstawowej opieki zdrowotnej w kontekście roli lekarza rodzinnego. Studia Ekonomiczne/Uniwersytet Ekonomiczny w Katowicach. 157: 149-156.

Jenkins, Richard. 2008. Social identity. Third edition. Abingdon, Oxon: Routledge.

Kennedy, Michael D. 2002. Cultural formations of postcommunism emancipation, transition, nation, and war. Minneapolis: University of Minnesota Press.

Kleinman, Arthur. 1988. The illness narratives: suffering, healing, and the human condition. Basic Books.

Koch, Erin. 2013. Free market tuberculosis. Managing epidemics in post-socialist Georgia. Nashville: Vanderbilt University Press.

Kowalska-Bobko, Iwona. 2017. Decentralizacja a systemy zdrowotne. W poszukiwaniu rozwiazań sprzyjajacych zdrowiu. Kraków: Wydawnictwo Uniwersytetu Jagiellońskiego.

Kubik, Jan. 2013. From Transitology to Contextual Holism: A Theoretical Trajectory of Postcommunist Studies. In: Kubik, Jan - Linch, Amy (eds.): Post-communism from within. Social justice, mobilization and hegemony. New York: New York University Press: 27-94. 
Mattingly, Cheryl - Garro, Linda (eds.). 2000. Narrative and the cultural construction of illness and healing. Berkeley, Los Angeles: University of California Press.

McKenna, Brian. 2012. The Clash of Medical Civilizations: Experiencing "Primary Care" in Neoliberal Culture. Fournal of Medical Humanities 33, 4: 255-272.

Riska, Elianne - Novelskaite, Aurelija. 2011. Professionalism and Medical Work in a Post-Soviet Society: Between Four Logics. Anthropology of East Europe Review 29, 1: 82-93.

Rylko-Bauer, Barbara - Farmer, Paul. 2002. Managed Care or Managed Inequality? A Call for Critiques of Market-Based Medicine. Medical Anthropology Quarterly 16, 4: 476-502.

Schecter, Kate. 2011. The Privatization of the Georgian Healthcare System. Anthropology of East Europe Review 29, 1: 16-22.

Stone, Deborah A. 1997: The Doctor as Businessman: The Changing Politics of a Cultural Icon. Fournal of Health Politics, Policy and Law 22, 2: 533-556.

Timmermans, Stefan - Berg, Marc. 1997. Standardization in Action: Achieving Local Universality Through Medical Protocols. Social Studies of Science 27: 273-305.

Välikangas, Anita - Seeck, Hannele. 2011. Exploring the Foucauldian Interpretation of Power and Subject in Organizations. Fournal of Management and Organization 17, 6: 812-827.

Verdery, Katherine. 1996. What was socialism, and what comes next? Princeton: Princeton University Press.

Vonderau, Asta. 2008. Models of Success in the Free Market: Transformations of the Individual Self-Representations of the Lithuanian Economic Elite. In: Schröder, Ingo W. - Vonderau, Asta (eds.): Changing economies and changing identities in postsocialist Eastern Europe. Berlin: LIT Verlag: 111-128.

Watson, Peggy. 2013. Catastrophic Citizenship and Discourses of Disguise: Aspects of Health Care Change in Poland. In: Watson, Peggy (ed.): Health care reform and globalisation. The US, China and Europe in comparative perspective. Abingdon: Routledge: 118-139.

Włodarczyk, Cezary. 2000. Podstawowa opieka zdrowotna jako kategoria polityki zdrowotnej. In: Czupryna, Antoni - Poździoch, Stefan - Ryś, Andrzej - Włodarczyk, Cezary (eds.): Zdrowie publiczne. Wybrane zagadnienia, t. I. Kraków: Vesalius: 213-228. 